
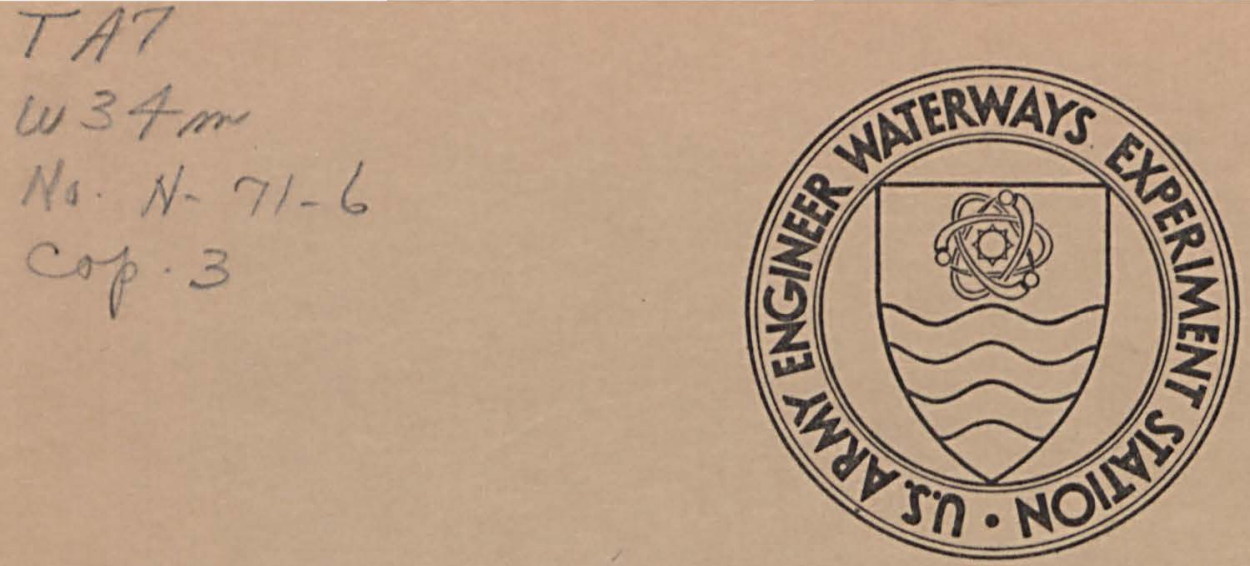

MISCELLANEOUS PAPER N-7I-6

\title{
DESTRUCTION OF MODEL EARTHEN TUNNE
BY INTERNAL EXPLOSIVE DETONATION
}

by

W. M. Gay, M. A. Vispi, J. K. Ingram, H. M. Taylor, Jr.
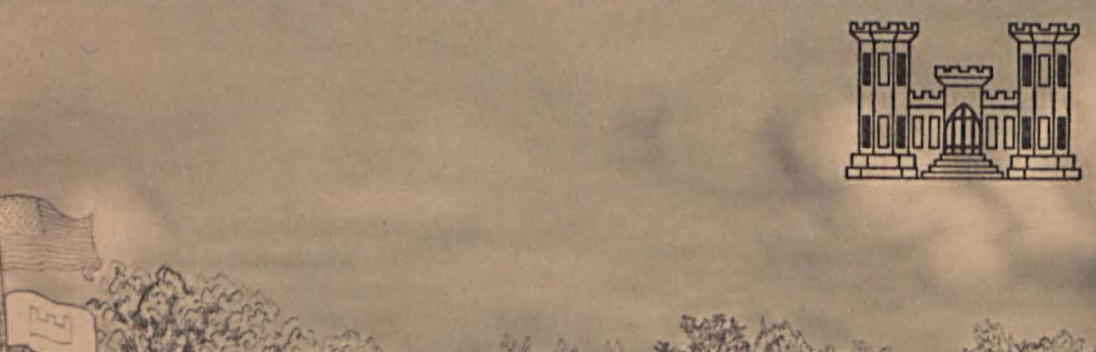

\section{RESEARCH CENTER LIBRARY \\ US APMY ENGINEER WATERWAYS EXPERIMENT STATINF VICKSBURG, MISSISSIPPI}

April 1971

Sponsored by Picatinny Arsenal

Conducted by U. S. Army Engineer Waterways Experiment Station, Vicksburg, Mississippi 


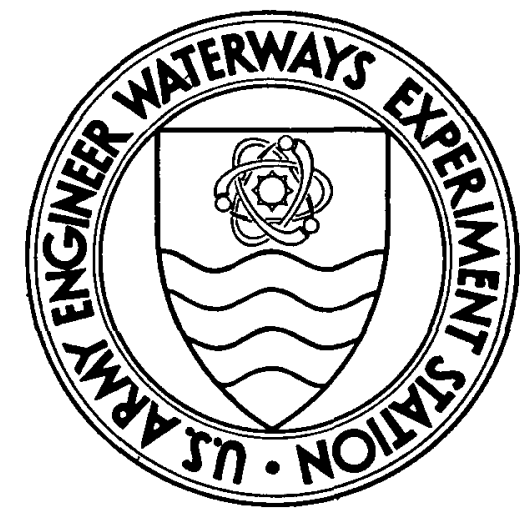

MISCELLANEOUS PAPER N-7I-6

\section{DESTRUCTION OF MODEL EARTHEN TUNNELS BY INTERNAL EXPLOSIVE DETONATION \\ by}

W. M. Gay, M. A. Vispi, J. K. Ingram, H. M. Taylor, Jr.

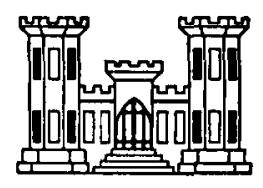

April 1971

Sponsored by Picatinny Arsenal

Conducted by U. S. Army Engineer Waterways Experiment Station, Vicksburg, Mississippi 
THE CONTENTS OF THIS REPORT ARE NOT TO BE USED FOR ADVERTISING, PUBLICATION, OR PROMOTIONAL PURPOSES. CITATION OF TRADE NAMES DOES NOT CONSTITUTE AN OFFICIAL ENDORSEMENT OR APPROVAL OF THE USE OF SUCH COMMERCIAL PRODUCTS. 


\section{Foreword}

This work was performed by the Soils, Construction Services, and $\mathrm{Nu}-$ clear Weapons Effects (NWED) Divisions of the U. S. Army Engineer Waterways Experiment Station (WES) during the period september 1967 through February 1968. The study was conducted for the Picatinny Arsenal. Work was accomplished under the direction of Mr. J. D. Day, Chief, Blast and Shock Section, Physical Sciences Branch, NWED, who coordinated the various phases of the project and under the general supervision of Mr. G. L. Arbuthnot, Jr., Chief, NWED, and Mr. L. F. Ingram, Chief, Physical Sciences Branch.

Project personnel were Messrs. M. A. Vispi and W. M. Gay of NWED; F. P. Leake, Jr., Instmumentation Services Division; R. M. Rudd, Photography Branch; H. M. Taylor, Jr., Soils Division; and R. N. Leggett, Construction Services Division. The report was written by Messrs. Gay, Vispi, Taylor, and J. K. Ingram.

The dimensional analysis and development of characteristic parameters were outlined by $\mathrm{Dr}$. A. J. Hendron of the University of Illinois. The soil analysis (Appendix A) was conducted by personnel of the Impulse Load Section, Soils Division.

COL John R. Oswalt, Jr., CE, was Director of the WES and Mr. J. B. Tiffany was Technical Director at the time of field testing. During the writing and publication of this report, COL Levi A. Brown, CE, and COL Ernest D. Peixotto, CE, were Directors and Mr. F. R. Brown was Technical Director. 


\section{Contents}

Page

Foreword . . . . . . . . . . . . . . . . . . . . . v v

Notation :........................... ix

Conversion Factors, British to Metric Units of Measurement . . . . . xi

Surmary . . . . . . . . . . . . . . . . . . . . . . xiii

Introduction . . . . . . . . . . . . . . . . . . . . . . 1

Objectives . . . . . . . . . . . . . . . . . . . I 1

Background . . . . . . . . . . . . . . . . . . 1

Procedure .. . . . . . . . . . . . . . . . . . . . . . . 2

Analytical approach ................... 2

Experimentel procedure .................. 4

Instmmentation ..................... 5

Other measurements . . . . . . . . . . . . . . . 7

Results .............................. 8

Transient measurements . . . . . . . . . . . . . 8

Postshot surveys .................... 8

Conclusions and Recommendations . . . . . . . . . . . . 12

Conclusions . . . . . . . . . . . . . . . 12

Recommendations . . . . . . . . . . . . . . . . 13

Literature Cited . . . . . . . . . . . . . . . . . . 13

Tables 1 and 2

Appendix A: Soil Analysis . . . . . . . . . . . . . . Al

Tables $A I$ and $A 2$ 


\section{Notation}

c Cohesion intercept of the soil, $1 \mathrm{~b} / \mathrm{ft} \mathrm{t}^{2}$ or psi

D Diameter of tunnel, ft

F Explosive energy per unit length of tunnel needed for destmuction, $\mathrm{ft}-\mathrm{Ib} / \mathrm{ft}$

$g$ Acceleration of gravity, $32.2 \mathrm{ft} / \mathrm{sec}^{2}$

H Depth of cover, ft

I Failure index, \%

I Length of tunnel, ft

Q Loading density, $1 \mathrm{~b} / \mathrm{ft}^{3}$

$\mathrm{V}$ Tunnel volume, $\mathrm{ft}^{3}$

W Charge weight, gr/ft

$\lambda$ Scale factor. Subscripts $m$ and $p$ indicate model and prototype, respectively. Other subscripts indicate parameter scaled

$\rho \quad$ Mass density of soil, slugs $/ f t^{3}$

$\sigma \quad$ Normal stress, psi

$\tau_{f} \quad$ Shear strength, psi

$\varnothing \quad$ Angle of internal friction of the soil, deg 


\section{Conversion Factors, British to Metric Units of Measurement}

British units of measurement used in this report can be converted to metric units as follows:

\section{Multiply}

cubic feet

feet

foot-pounds

foot-pounds per foot

grains

grains per foot

inches

pounds

pounds per cubic foot

pounds per square foot

pounds per square inch

slugs per cubic foot

tons per square foot

\begin{tabular}{l}
$\frac{1}{\text { By }}$ \\
\hline 0.02832 \\
0.3048 \\
1.356 \\
4.448 \\
64.80 \\
0.2126 \\
25.40 \\
0.4536 \\
16.02 \\
47.88 \\
6.895 \\
0.5154 \\
95.76
\end{tabular}

To Obtain

cubic meters

meters

meter-newtons

meter-newtons per meter

milligrams

milligrams per meter

millimeters

kilograms

kilograms per cubic meter

newtons per square meter

kilonewtons per square meter

grams per cubic meter

kilonewtons per square meter 


\section{Summary}

This report describes a series of explosive demolition tests on small horizontal tunnels in soil using line charges of Primacord.

The objectives of the tests were to study the mechanisms of failure of model tunnels in earth when subjected to internal explosions and to develop a means of predicting failure considering the soil properties (detailed in Appendix A) and tunnel geometry.

A nondimensional approach to data analysis was proposed to account for the many test variables, including soil properties, geometry, and explosive loading density; although only a limited number of tests were performed, this method of approach appears to be valid. Results for the dominant test condition investigated (depth of cover $H$ four times the tunnel diameter D) indicate that a minimum loading density of $0.3 \mathrm{lb} / \mathrm{ft} 3$ of Primacord is required to destroy tunnels in a strong, cohesive soil.

A dimensionless plot was constructed from the results of these tests. This plot includes only the condition $\mathrm{H} / \mathrm{D}=4$; therefore, with this plot and a known tunnel size, the amount of Primacord to destroy a tunnel of $H / D=4$ in various strength soils can be determined. 


\section{DESTRUCTION OF MODEL EARTHEN TUNNELS}

BY INTERNAL EXPLOSIVE DETONATION

Introduction

\section{Objectives}

1. The objectives of this study were:

a. To study the mechanisms of failure of small cylindrical tunnels in earth when subjected to internal explosions.

b. To develop a means of predicting failure which takes into consideration the soil properties as well as geometry.

\section{Background}

2. A continuing need exists for improved means of destroying underground complexes currently in use by the enemy in Southeast Asia. It is expected that there will be a long-standing need for such methods because of the tactics used in this area and perhaps other areas of the world.

3. The U. S. Army Engineer Waterways Experiment Station (WES), along with other Corps of Engineers and Army Materiel Command laboratories and their contractors, participated in tunnel destruction experiments $^{1,2}$ conducted at the Clark Hill Reservoir in South Carolina. The WES participation consisted of:

a. Measuring the blast pressure histories at several locations on the roof of the tunnels.

b. Measuring motions of the tunnel roof with accelerometers and high-speed photography.

c. Postshot damage surveys.

d. Coordination of the soil testing program.

e. Development of a crude analytic failure prediction method.

4. For the Clark Hill tests, the Picatinny Arsenal, with assistance from the U. S. Bureau of Mines and Miller Research, Inc., developed a number of detonable gas mixtures and methods of emplacement and designed the initial tunnel destruction experiments. The intent of the study reported 
herein was to investigate the use of Primacord* charges 3,4 (in Iieu of detonable gas) detonated in small-scale cylindrical tunnels.

\section{Procedure}

\section{Analytical approach}

5. Dimensional analysis was used to scale the effects of this model study. The parameters assumed to control the behavior of the tunnels (fig. 1) are:

$\varnothing=$ angle of internal friction of the soil, deg

$c=$ cohesion intercept of the soil, $I \mathrm{~b} / \mathrm{ft}^{2} * *$

$\rho=$ mass density of the soil, slugs $/ \mathrm{ft}^{3}$

$D=$ tunnel diameter, ft

$H=$ tunnel depth, ft (distance from ground surface to the top of the tunnel)

$F=$ energy of explosive per unit length of tunnel, $\mathrm{ft}-\mathrm{Ib} / \mathrm{ft}$

$g=$ acceleration due to gravity, $f t / \mathrm{sec}^{2}$

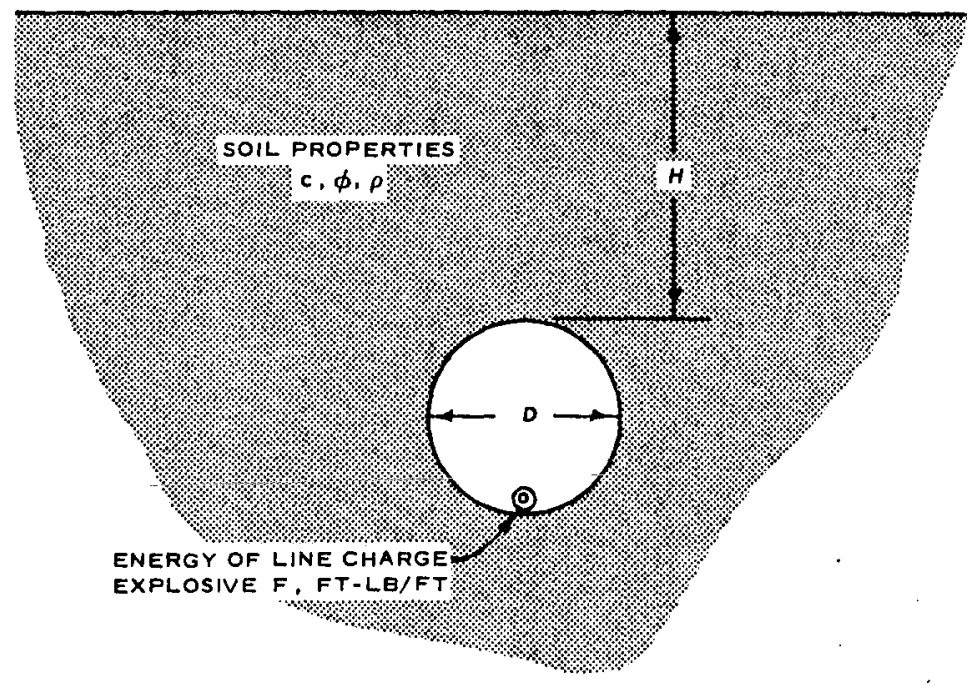

Fig. 1. Tunnel destruction test variables

* A trade name of the Ensign-Bickford Co. for a linearly detonating high explosive made up of PETN (pentaerythriteranitrate) high-velocity explosive core with a uniform detonation velocity of $21,000 \mathrm{ft} / \mathrm{sec}$.

* A table of factors for converting British units of measurement to metric units is presented on page $x i$. 
Significant dimensionless parameters or Pi terms are

$$
\varnothing, \frac{H}{D}, \frac{g \rho D}{c} \text {, and } \frac{F}{c D^{2}}
$$

6. For an exact model test, each of these parameters must be held equal for model and prototype. Thus, if the scale factor for a given variable is denoted by $\lambda$, it may be seen that

$$
\frac{\mathrm{H}_{m}}{\mathrm{D}_{m}}=\frac{\mathrm{H}_{\mathrm{p}}}{\mathrm{D}_{\mathrm{p}}} \text { or } \frac{\mathrm{D}_{\mathrm{m}}}{\mathrm{D}_{\mathrm{p}}}=\frac{\mathrm{H}_{\mathrm{m}}}{\mathrm{H}_{\mathrm{p}}}=\lambda_{\mathrm{D}}=\lambda_{\mathrm{H}}=\lambda_{\mathrm{L}}
$$

where $\lambda_{L}$ is the length scale factor and the subscripts $m$ and $p$ denote the model and the prototype, respectively. Similarly, since $\lambda_{\mathrm{g}}=1$, $\lambda_{c} / \lambda_{P}=\lambda_{D}=\lambda_{L}, \lambda_{F} / \lambda_{c}=\lambda_{H}^{2}=\lambda_{L}^{2}$, and $\phi_{m}=\phi_{p}$.

7. Using the same material in all tests makes it impossible to scale according to $\lambda_{c} / \lambda_{\rho}=\lambda_{I}$. Thus an exact model test cannot be conducted and it is desirable to consider an alternate procedure. This alternative consists of holding $\varnothing$ constant and approximately equal to the prototype value, which allows plotting of test results in the form given by fig. 2 .

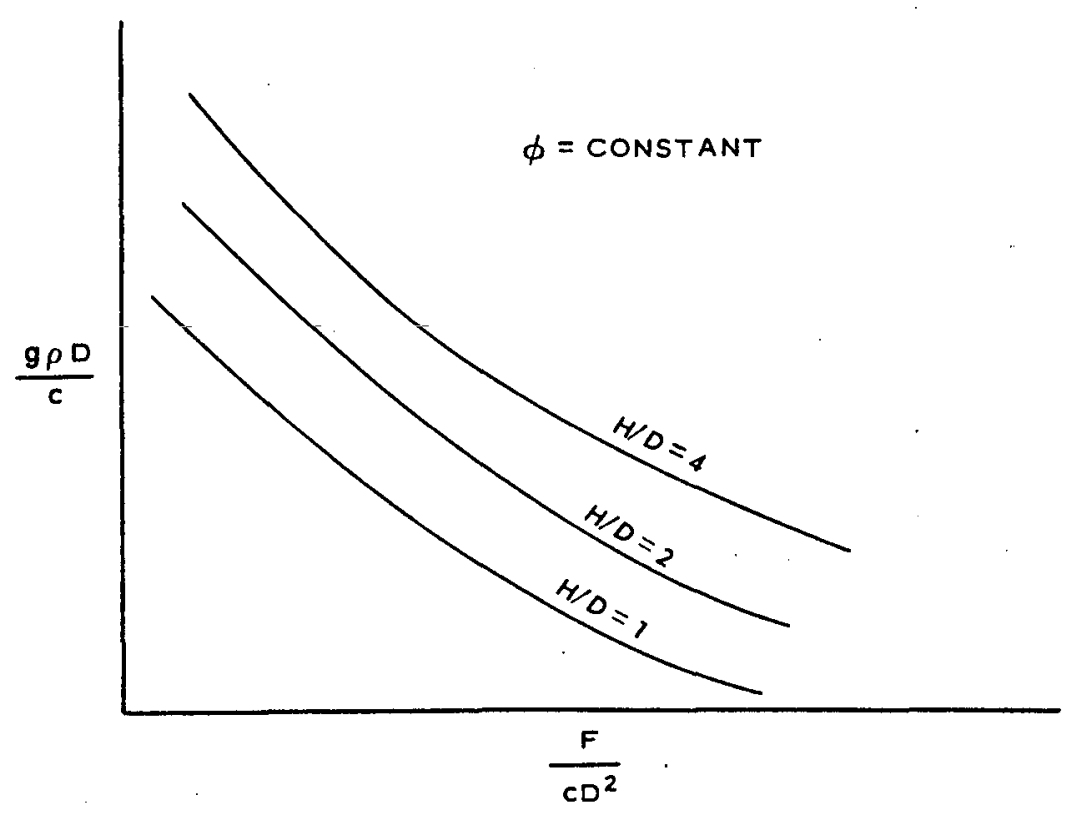

Fig. 2. Nondimensional tunnel failure relation 
The nondimensional relation $g \rho D / c$ may be considered to represent a soil strength characteristic and the relation $F / C D^{2}$ to represent explosive energy yield. By plotting these relations, characteristic response curves may be developed to determine the explosive energy required to fail a tunnel of given dimensions and burial within a given strength material.

8. The shape of the curve cannot be predicted but must be determined experimentally. Each point requires several tests since for a given $g \rho D / C$ and $H / D$ the explosive energy $F$ required for destruction can only be found by trial and error.

9. It is recognized that a more detailed analysis of this problem might be presented. Such an analysis could include the pressure at the tunnel wall from the explosion, gas flow properties, additional soil variables (i.e. void ratio, porosity, saturation, or modulus), and others. However, such refinements were not felt to be justified under the scope of this study.

10. Finally, it is emphasized that the energy $F$ and not the weight $W$ of the explosive is the important variable." Thus the test results may be applied to different explosives provided the weights of explosives used are adjusted to provide the required energy.

11. It is difficult to define a positive tunnel failure criterion; therefore, to minimize the differences resulting from human judgment, a failure criterion was established as follows: failure occurred if the postshot survey showed less than $70 \%$ of the original volume to be available for occupancy. The tunnel was then considered to have been destroyed. On this basis a numerical index of failure I was computed with $30 \%$ fallback taken as $100 \%$ failure.

Experimental procedure

12. Original plans were to perform many tests with sufficient variables to establish a family of curves (fig. 2) for the parameter H/D ; however, because of funding limitations, the test program was limited as show in table 1 .

13. Primacord charges of varying loading densities $Q$ (pounds of explosive per cubic foot of tunnel) were detonated on the bottom of the cylindrical tunnels. The portal of each tunnel was stemmed (sealed) so 
that the effect of the explosion was contained within the tunnel.

14. The test site was located on a newly acquired tract of land adjacent to the existing WES reservation at Vicksburg. A 20- by 8-ft instrumerstation trailer and a 30-kva generator were positioned near the site to house and power the recording equipment. The soil was cleared and grubbed of all overburden and then graded such that vertical shelves of different heights were exposed to facilitate augering of horizontal, circular tunnels with a skid-mounted drill rig (fig. 3).

15. Two soil test pits were excavated, one at each end of the site. Detailed soil properties of samples obtained from these pits are discussed in Appendix A. The soil is an extremely strong silty clay of the Vicksburg loess formation. Unconfined shear strength of approximately 5 tons $/ \mathrm{ft}^{2}$ was obtained at a moisture content of $22 \%$. Based upon best available data, it is believed that this soil is as strong or stronger than most soils in Vietnam where tunnels have been found. The tests, therefore, are considered representative of an upper bound for soil strength.

16. A 5-in.-diam pilot hole was first drilled and later reamed to the desired tunnel diameter. It was possible to drill a straighter tunnel by using this method than with the larger auger. Several tunnels were drilled at the beginning of the program before testing. This technique of predrilling was unsatisfactory because cracks propagated from adjacent tunnels when the charges were detonated. The procedure was modified by drilling only one tunnel and testing it before augering the next. Instrumentation

17. An assortment of electronic measurements were made in 0.5-ftdiam tunnels 1-6 (table 1). These included pressure-time histories inside the tunnels, accelerations at the surface of the soil and at middepth between the tunnel roof and the surface, and displacement histories of the ground surface at the tunnel center line. Fig. 4 shows gage locations. Approximately eight channels were recorded for each test. Gages used were Endevco 2500-g Model 226I 5 and CEC 500-g. Model 4-202-0001 ${ }^{6}$ accelerometers for the motion measurements and WES-made IF cells ${ }^{7}$ for the pressure measurements. A linear motion potentiometer was used to measure the displacement histories. No electronic measurements were attempted on tunnels 7-14. 


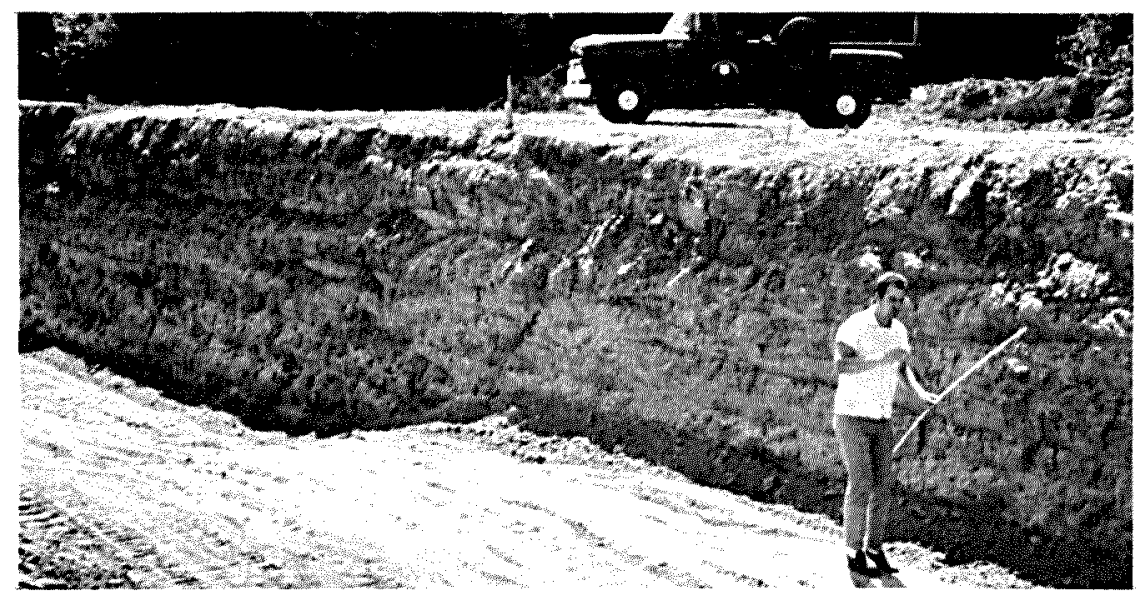

\section{a. Tunnel site after grading}

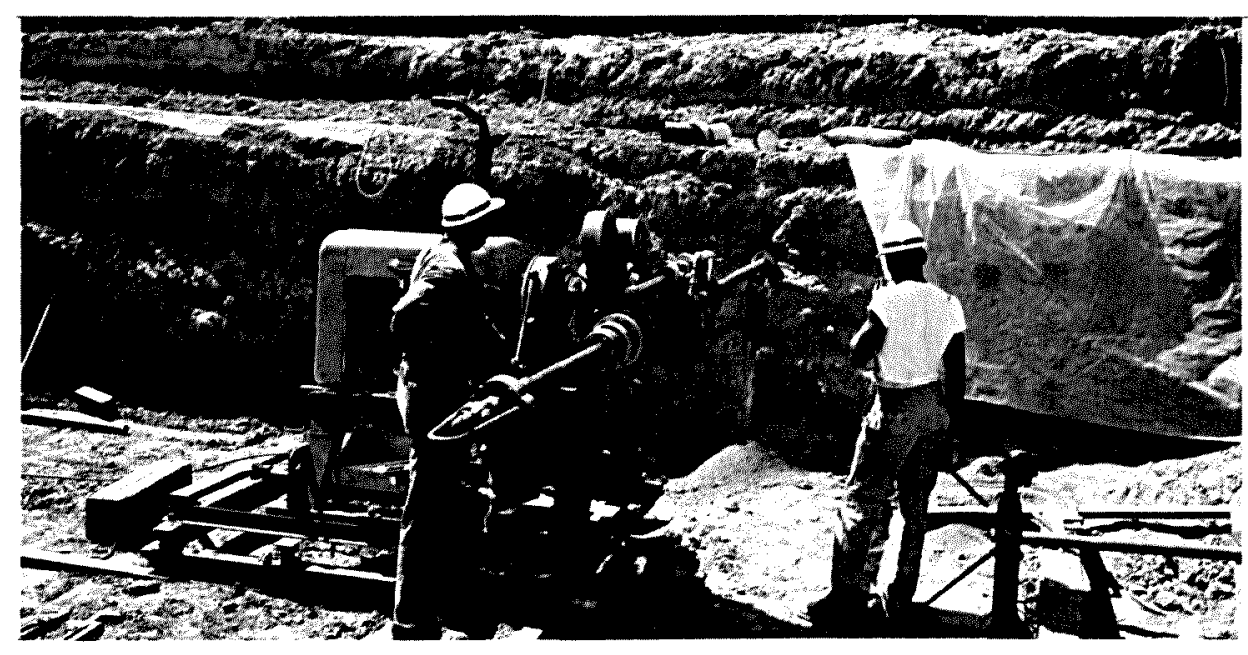

b. Drilling operation

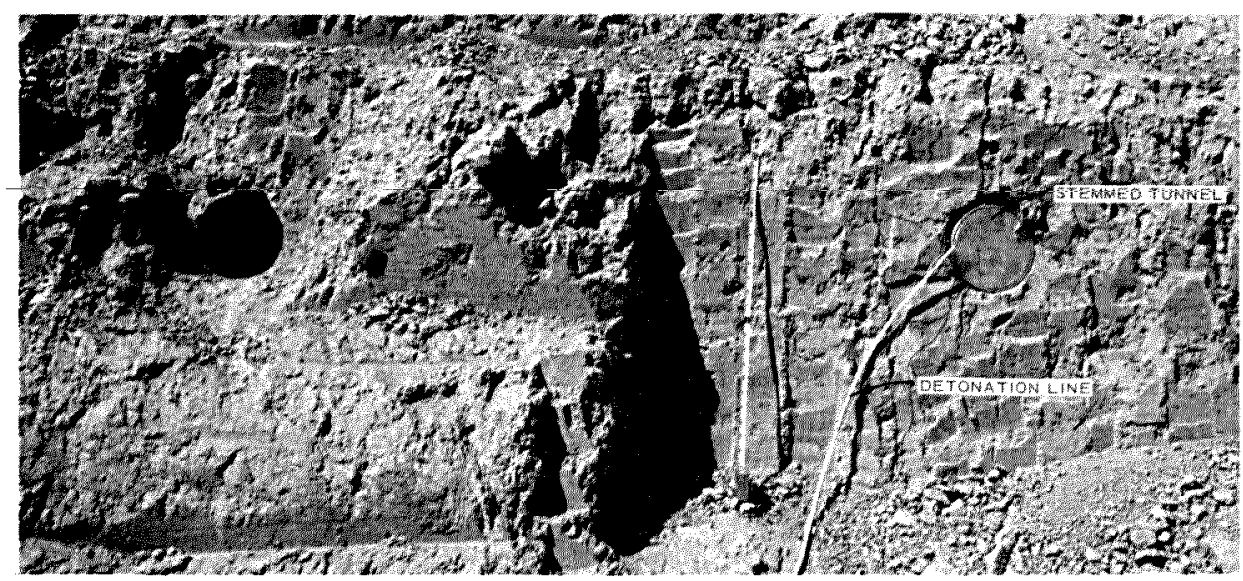

c. Stemmed tunnel prior to detonation

Fig. 3. Tunnel preparation 


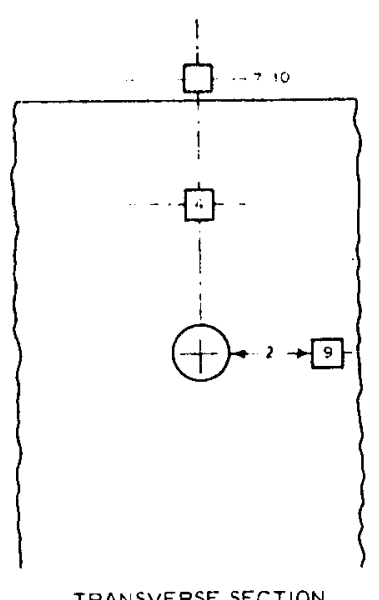

TRANSVERSE SECTION AA

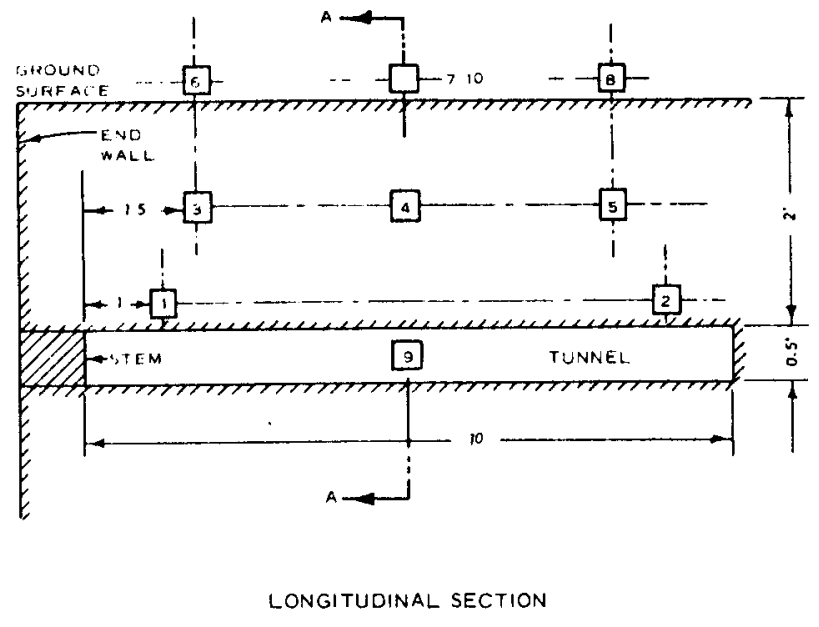

LEGEND

PRESSURE GAGES

MOTION GAGES

DISPLACEMENT GAGE

\section{Fig. 4. Gage location diagram}

18. Pressure gages were mounted in a 1-in.-diam thin-wall aluminum pipe which was in turn grouted into a 1-1/4-in. hole drilled from the surface to the tunnel roof. Gages were isolated from the aluminum pipe with a nylon sleeve to prevent ringing. Motion gages were grouted in place with a density-matching soil cement. Surface accelerometers were mounted on a 3-in.-diam aluminum plate fastened to the ground with three corkscrew type rods.

\section{Other measurements}

19. In addition to the electronic measurements, a Fastax movie camera operating at 2000 frames/sec was used on most shots to photograph the surface ground motion against a graduated backdrop (fig. 5). The camera was aimed along the ground surface above the tunnel center line at the reference backdrop placed at right angles to the tunnel center line and about $10 \mathrm{ft}$ behind the end of the tunnel. This method of transient surface motion measurement was used exclusively on tunnels 7-14.

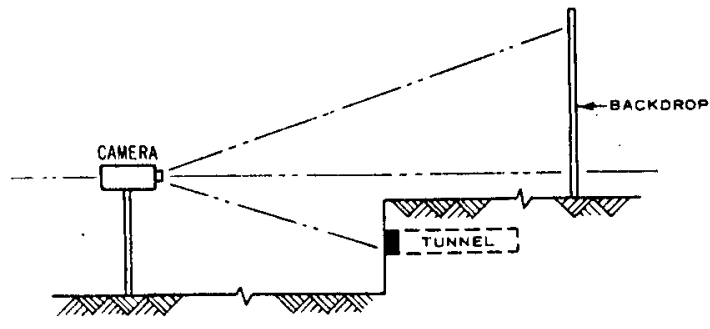

Fig. 5. Surface motion photography 
20. Preshot and postshot surveys were run on the ground surface above the tunnel to determine the amount of permanent ground displacement. Tunnels 4 and 6 were sectioned at midlength to determine the soil fracture patterns and extent of the rupture zone.

21. Fallback material was scraped out of tunnels 6 and 9 , and weight and volume were measured to determine the percent fallback that occurred. This was not possible on tunnels that were badly cracked or essentially closed up with fallback material (tunnels $5,7,8,10,11$, and 12).

\section{Results}

\section{Transient measurements}

22. Table 2 gives the peak pressures, accelerations, and displacements obtained in 0.5-ft-diam tunnels 1-6. No transducers were used on tunnels 7-14; only high-speed photography was used to determine surface displacements.

Postshot surveys

23. Preshot and postshot surveys of the ground surface above tunnels 7 and 9-14 are shown in fig. 6. The fallback debris in tunnels 6 and 9 was scraped out, and the weight and volume were measured. From these data, the closure of tunnel 6 was calculated to be $9.5 \%$, and the closure of tunnel 9 to be $6.25 \%$. This operation could not be performed on tunnels 5 , $7,8,10,11$, and 12 because of excessive caving that made removal of the fallback impossible. Table 1 remarks on the postshot damage observation of all tunnels tested. Typical postshot views of tunnels 6 and 9 are shown in fig. 7 .

24. Although considerable damage was done in the form of longitudinal and radial cracking in the soil in all tunnels (fig. 8a), positive failure did not occur until the $0.364-\mathrm{lb} / \mathrm{ft}^{3}$ shot for 0.5 -ft-diam tunnel 8 and the $0.291-1 \mathrm{~b} / \mathrm{ft}^{3}$ shot in 1.0-ft-diam tunnel 10. Typical surface cracking patterns from usable and completely ruptured tunnels are shown in fig. 8.

25. The soil above and around many of the tunnels (tunnels $3,4,6$, 9, 11, 13, and 14) experienced considerable brittle spallation, but insufficient amounts of the soil collapsed to cause complete closure. 


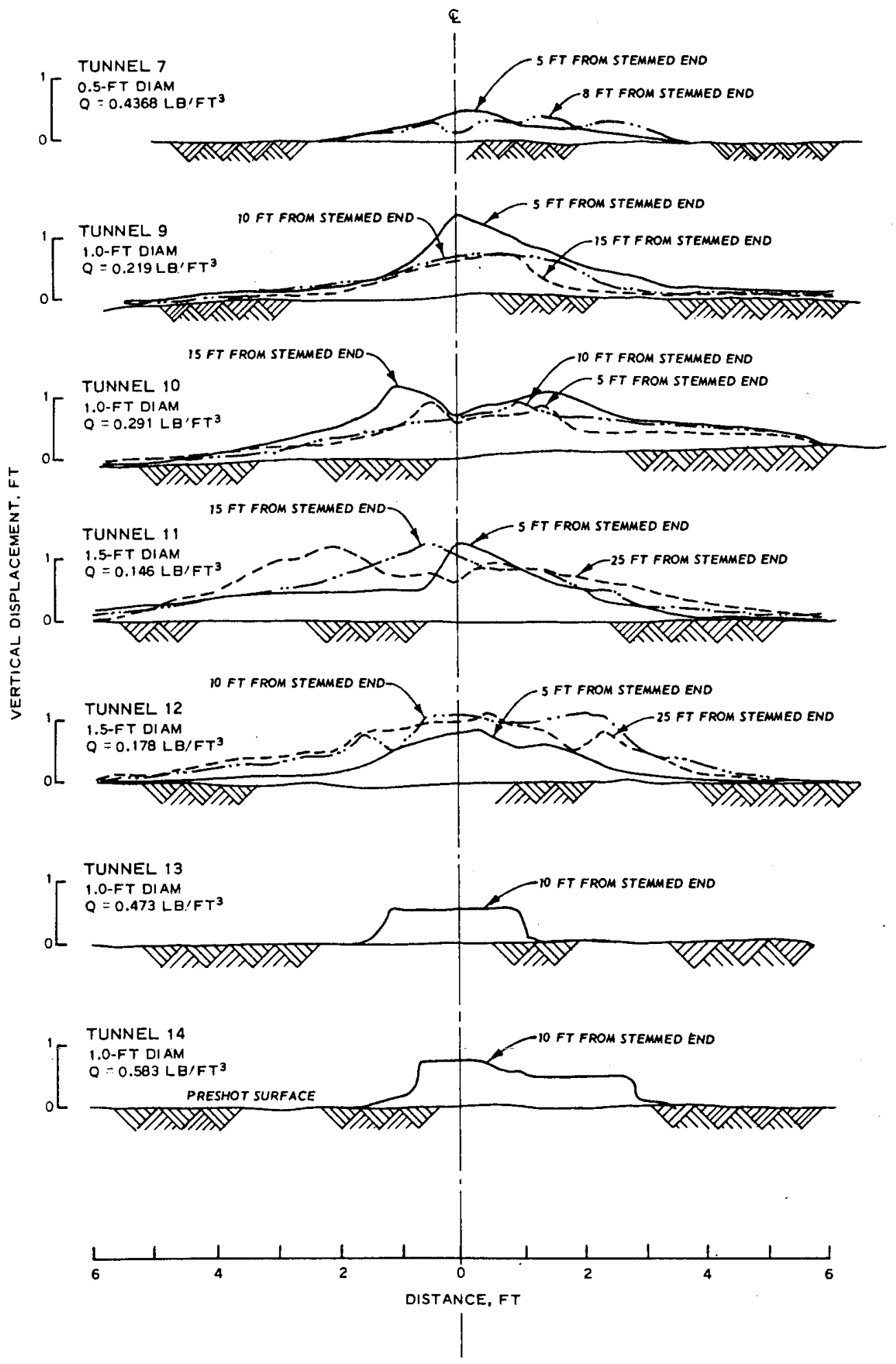

Fig. 6. Postshot transverse surface profiles for tunnels 7 and 9-14 


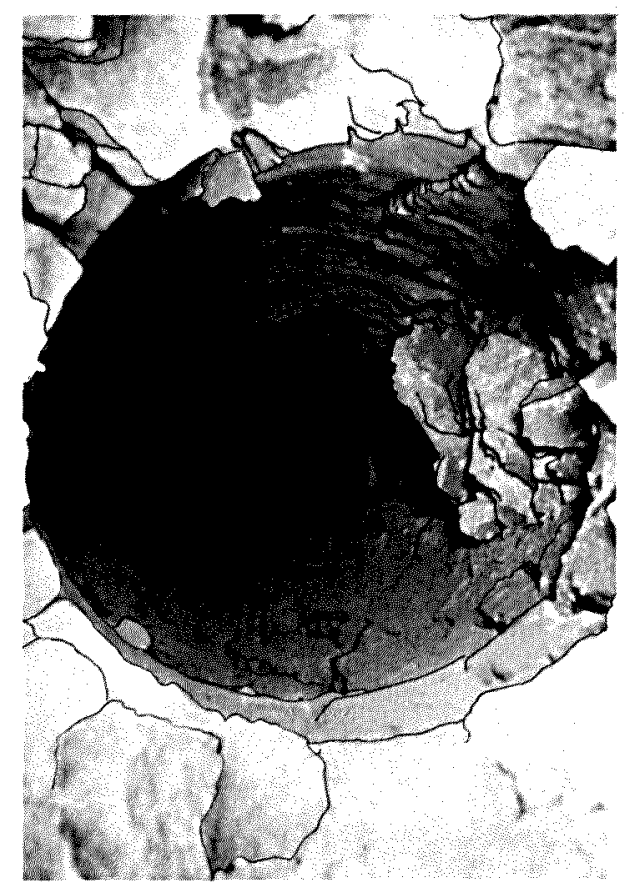

a. Tunnel interior after detonation, tunnel 9

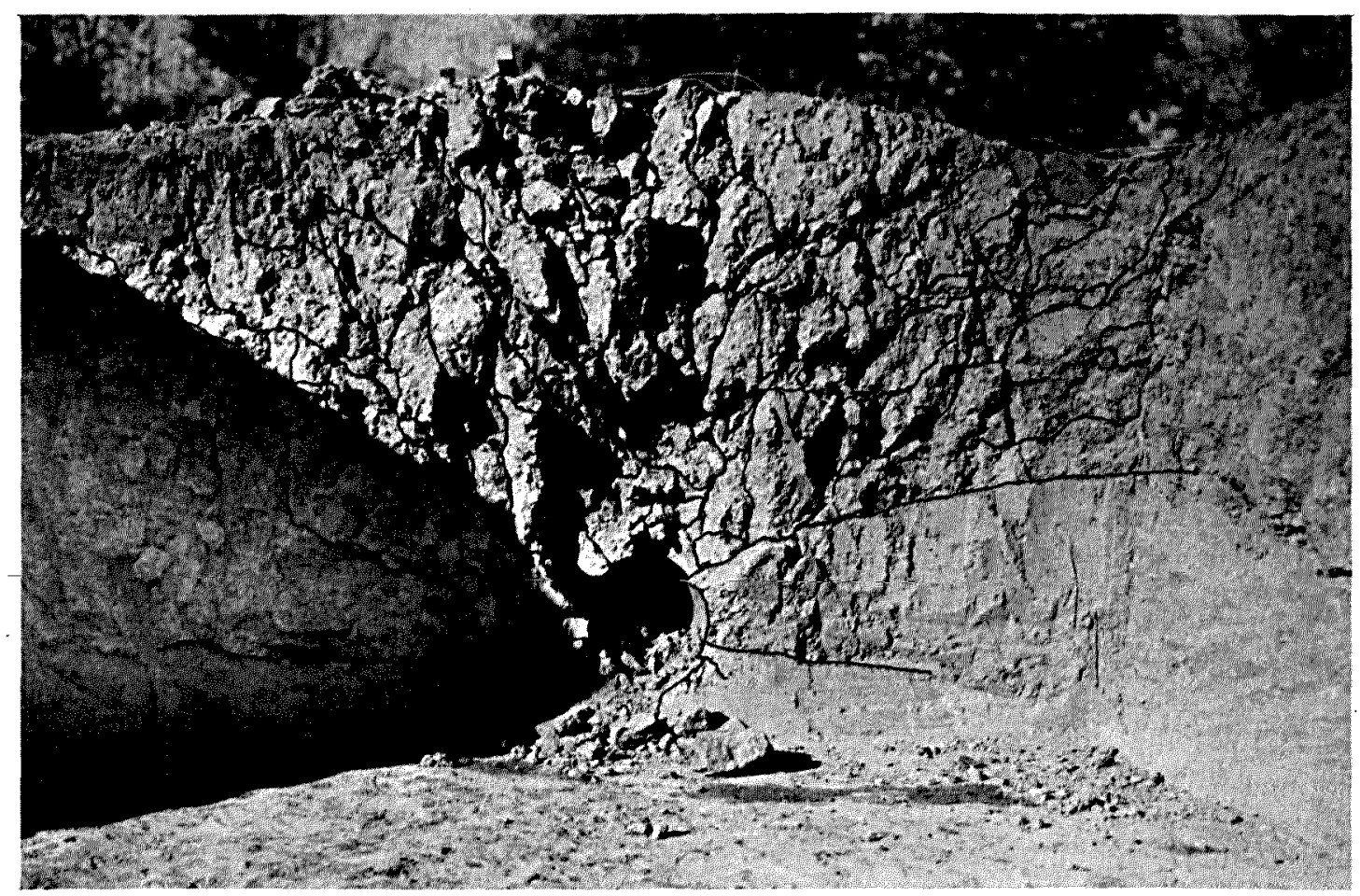

b. Midlength transverse through tunnel 6

Fig. 7. Postshot views of typical tunnels which did not fail 


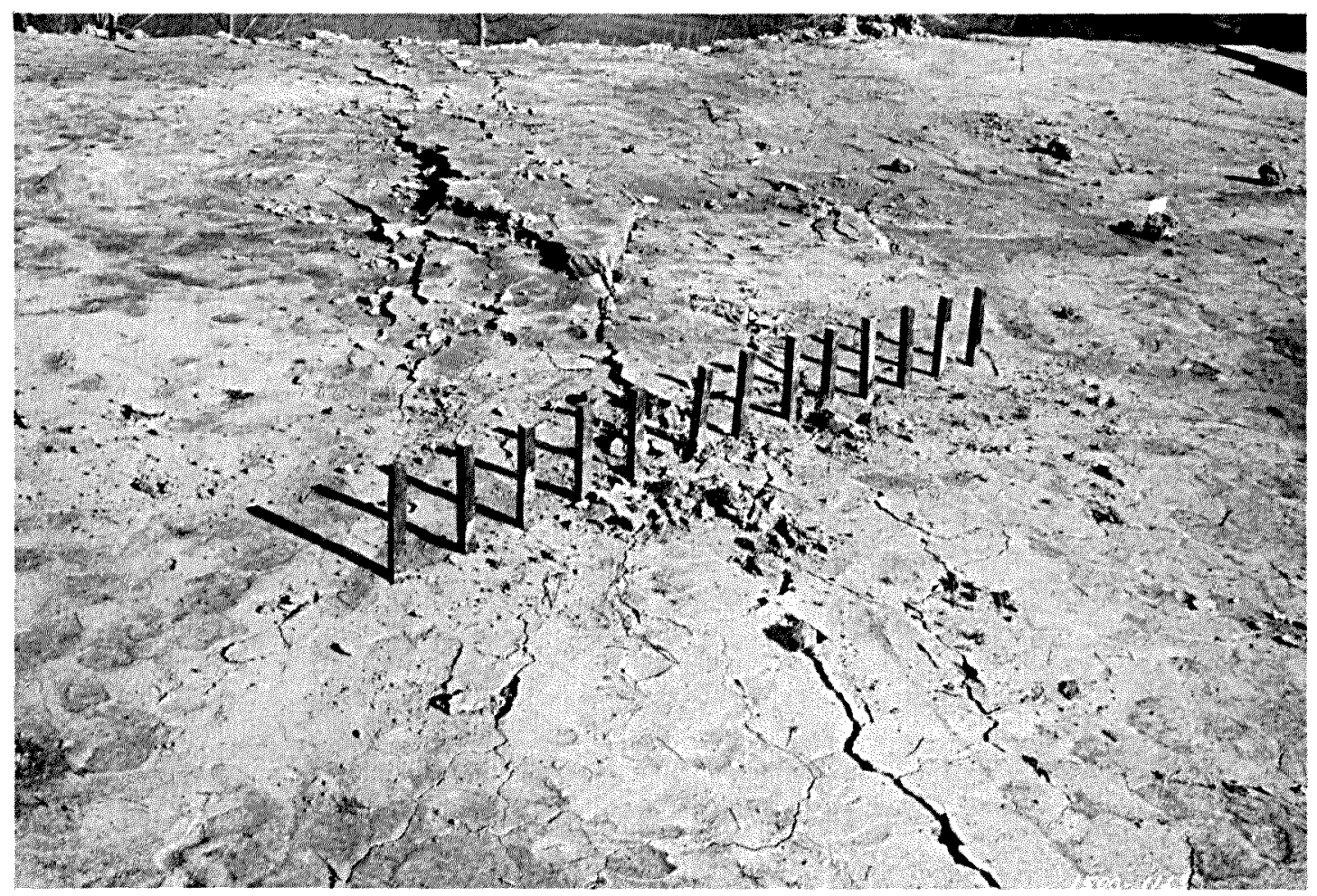

a. Surface crack pattern, usable tunnel 13

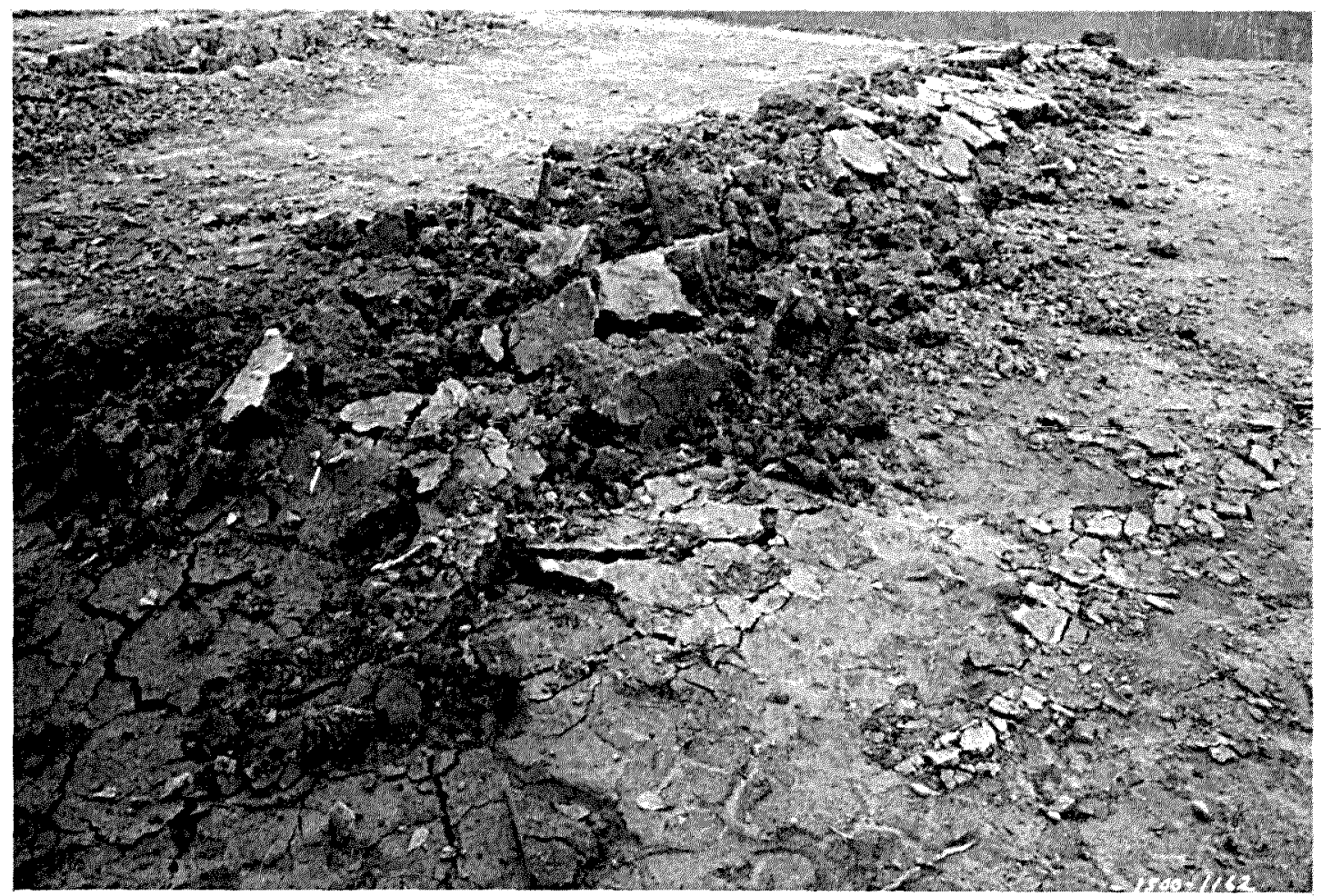

b. Rupture surface, destroyed tunnel 12

Fig. 8. Typical surface views, usable and destroyed tunnels 


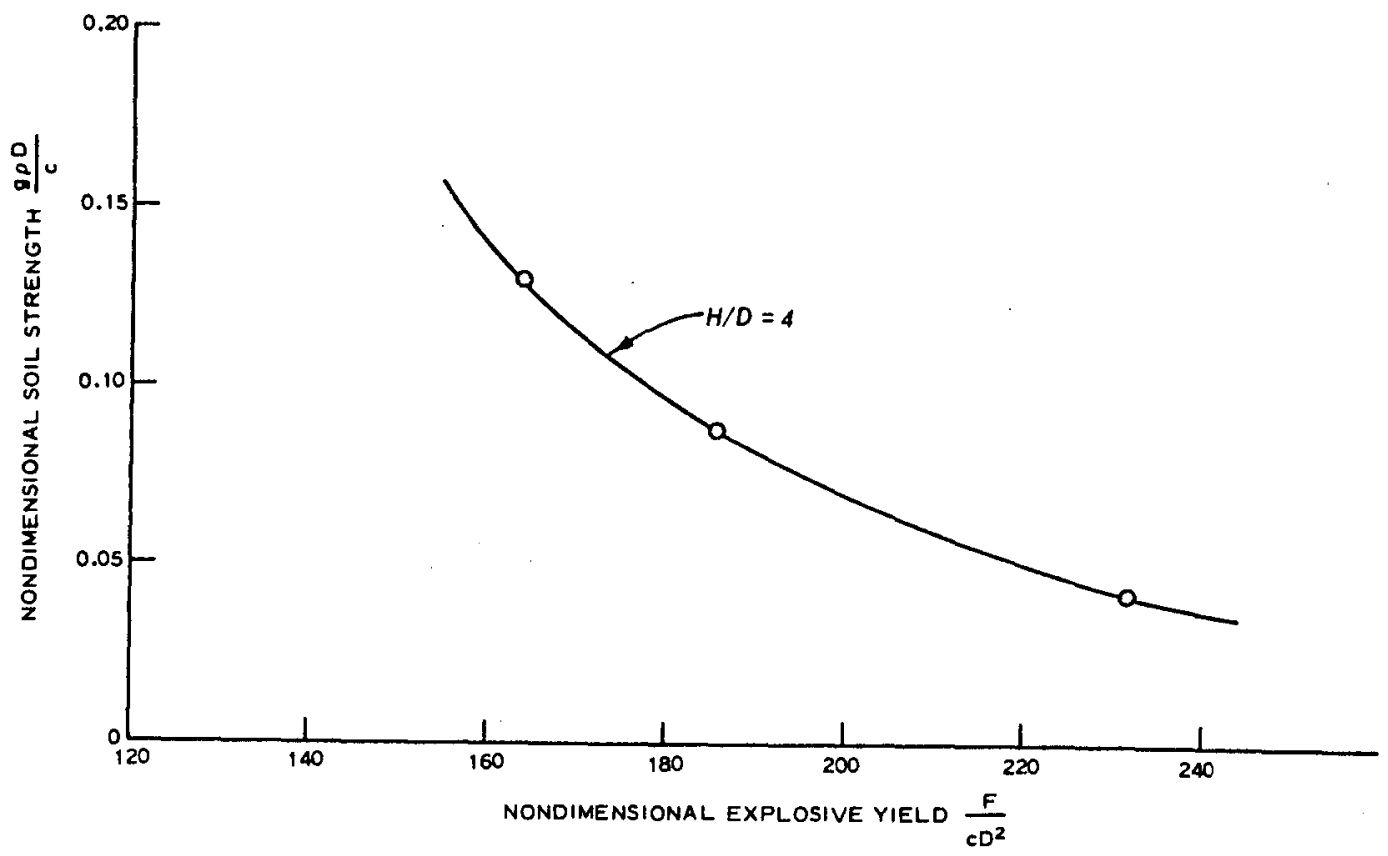

Fig. 9. Empirically derived tunnel failure relation for $\mathrm{H} / \mathrm{D}=4$ (based on tunnels which were completely demolished)

26. Fig. 9 is a plot of dimensionless Pi terms constructed from the results of the tunnel shots. This plot relates to an $\mathrm{H} / \mathrm{D}$ ratio of 4 . By using this plot and knowing the size tunnel, the amount of Primacord needed to destroy a tunnel of $\mathrm{H} / \mathrm{D}=4$ in various strength soils can be determined. Approximately $0.3 \mathrm{Ib}$ of Primacord per cubic foot of tunnel volume is needed to destroy tunnels of the type tested.

\section{Conclusions and Recommendations}

\section{Conclusions}

27. Three tunnel diameters, varying by a factor of three, were tested. It was found that a minimum $Q$, or explosive loading density, of approximately $0.3 \mathrm{lb}$ of Primacord per cubic foot of tunnel was required to achieve failure. Since the $\mathrm{L} / \mathrm{D}$ and $\mathrm{H} / \mathrm{D}$ ratios were held constant, and approximately the same $Q$ was required for failure of the tunnels tested, it is suggested that modeling tunnel destruction is feasible. However, additional tests should be conducted for verification. 
28. Tunnel destruction tests should be continued in different soils. In the interest of economy, the electronic instrumentation could be eliminated or reduced. High-speed photography and damage surveys are effective determinates and should be emphasized. Soil tests are required to document test conditions.

29. Experiments should be conducted with point-isource charges and the results compared with linear charges of equivalent explosive yield. This is recommended because of the belief that, in most tactical situations, point-source or satchel-type charges would be easier to place.

30. It is recommended that exploration of additional test sites to find soil materials with shear strengths of approximately 2000, 1000, and $500 \mathrm{lb} / \mathrm{ft}^{2}$ be initiated. The recommended order of priority for testing is 1000-, 2000-, and then 500-lb/ $\mathrm{ft}^{2}$ materials. It is expected that suitable sites can be located within a reasonable distance of WES.

\section{Iiterature Cited}

1. Gay, W. M. et al., "Destruction of Earth Tunnels with Explosive Gases, Waterways Experiment Station Participation in Project Rathole" (in preparation), U. S. Army Engineer Waterways Experiment Station, CE, Vicksburg, Miss.

2. Burgess, D., Murphy, J., and Hanna, N., "Destruction of Earthen Tunnels by Gas Detonation," Progress Report No. 12, Nov 1966, U. S. Department of Interior, Bureau of Mines, Pittsburgh, $\mathrm{Pa}$.

3. "Primacord Detonating Fuse," 1960, Ensign-Bickford Co., Simsbury, Conn.

4. Headquarters, Department of the Army, "Explosives and Demolitions," Field Manual FM 5-25, May 1959, Washington, D. C.

5. "Endevco Instruction Manual; Models 2260 and 2261 Piezoresistive Accelerometer Instruction Guides," Feb 1968, Endevco Corporation, Pasadena, Calif.

6. "Bulletin 4202B," Jan 1963, Transducer Division, Consolidated Electrodynamics Corporation, Monrovia, Calif.

7. Faust, R. W. and Ingram, J. K., "Development of On-Structure Stress Gages," Technical Report No. 1-801, Nov 1967, U. S. Army Engineer Waterways Experiment Station, CE, Vicksburg, Miss. 
Table 1

Test Program and Results

\begin{tabular}{|c|c|c|c|c|c|c|c|c|c|c|c|}
\hline $\begin{array}{c}\text { Height- } \\
\text { Dianeter } \\
\text { Ratio } \\
\text { H/D } \\
\end{array}$ & $\begin{array}{c}\text { Length- } \\
\text { Diameter } \\
\text { Ratio } \\
\text { L/D } \\
\end{array}$ & Tunne 1 & $\begin{array}{l}\text { Diameter } \\
\text { D, ftt }\end{array}$ & $\begin{array}{c}\text { Depth } \\
\text { Below } \\
\text { Surface } \\
\mathrm{H}, \mathrm{ft} \\
\end{array}$ & $\begin{array}{l}\text { Length } \\
\text { L, It }\end{array}$ & $\begin{array}{l}\text { Volume } \\
\mathrm{v}, \mathrm{ft}^{3} \\
\end{array}$ & $\begin{array}{c}\text { Charge } \\
\text { weight } \\
\text { w } \\
\text { gr/ft } \\
\end{array}$ & $\begin{array}{c}\text { Total } \\
\text { Charge } \\
\text { weight } \\
\text { Ib } \\
\end{array}$ & $\begin{array}{l}\text { Explosive } \\
\text { Loading } \\
\text { Density } \\
\mathrm{Q}, 1 \mathrm{~b} / \mathrm{ft}^{3} \\
\end{array}$ & $\begin{array}{l}\text { Failure } \\
\text { Index } \\
I, \&^{* *}\end{array}$ & Damage Observation \\
\hline \multirow[t]{12}{*}{4} & \multirow{11}{*}{20} & 1 & \multirow[t]{8}{*}{0.5} & \multirow[t]{8}{*}{2.0} & \multirow[t]{8}{*}{10.0} & \multirow[t]{8}{*}{1.964} & 25 & 0.0357 & 0.0182 & 10 & Few small cracks \\
\hline & & 2 & & & & & 50 & 0.0714 & 0.0364 & 10 & Few small cracks \\
\hline & & 3 & & & & & 100 & 0.1428 & 0.0728 & 20 & Large longitudinal cracks, some fallback \\
\hline & & 4 & & & & & 200 & 0.2856 & 0.1456 & 20 & Large longitudinal cracks, some fallback \\
\hline & & 5 & & & & & 400 & 0.5712 & 0.2912 & 100 & Approximately $40 \%$ fallback \\
\hline & & 6 & & & & & 300 & 0.4284 & 0.2184 & 30 & $\begin{array}{l}\text { Severe longitudinal and radial cracks, } \\
9.5 \% \text { fallback }\end{array}$ \\
\hline & & 7 & & & & & 600 & 0.8568 & 0.4368 & 100 & Completely demolished \\
\hline & & 8 & & & & & 500 & 0.7140 & 0.3640 & 100 & Completely demolished \\
\hline & & 9 & 1.0 & 4.0 & 20.0 & 15.70 & 1200 & 3.43 & 0.219 & 20 & $\begin{array}{l}\text { Large lanfitudinal and radial cracks, } \\
6.5 \% \text { fallback }\end{array}$ \\
\hline & & 10 & 1.0 & 4.0 & 20.0 & 15.70 & 1600 & 4.57 & 0.292 & 100 & Completely demolished, $>50 \%$ rallback \\
\hline & & 11 & 1.5 & 6.0 & 30.0 & 52.90 & 1800 & 7.71 & 0.146 & 50 & Longitudinal cracks, destroyed near center \\
\hline & 13 & 12 & 1.5 & 6.0 & 20.0 & 35.30 & 2200 & 6.29 & 0.178 & 100 & $\begin{array}{l}\text { Essentially destroyed, approximately } 30 \% \\
\text { fallback }\end{array}$ \\
\hline 8 & 20 & 13 & 1.0 & 8.0 & 20.0 & 15.70 & 2600 & 7.43 & 0.473 & 30 & Moderate longitudinal cracking \\
\hline 8 & 20 & 14 & 1.0 & 8.0 & 20.0 & 15.70 & 3200 & 9.15 & 0.583 & 30 & Severe longitudinal and radial cracking \\
\hline
\end{tabular}

* Pounds of explosive per cubic foot of tunhel.

* Pounds of explosive per cubic foot of tunnel.

Table 2

Peak Transient Data Tabulation

\begin{tabular}{|c|c|c|c|c|c|c|c|c|c|c|c|}
\hline \multirow[b]{2}{*}{ Tunnel } & \multirow{2}{*}{$\begin{array}{c}\text { Explosive } \\
\text { Losding Density } \\
Q, \mathrm{Ib} / \mathrm{ft}^{3} * \\
\end{array}$} & \multicolumn{2}{|c|}{ Peak Pressire, psi } & \multicolumn{7}{|c|}{ Peak Acceleration, g's } & \multirow{2}{*}{$\begin{array}{c}\text { Peak Dis- } \\
\text { placement, ft } \\
\text { Gage } 10 \\
\end{array}$} \\
\hline & & Gage $1^{* *}$ & Gage ? & Gage 3 & Gage 4 & Gage 5 & Gage 6 & Gage 7 & Gage 8 & Gage 9 & \\
\hline 1 & 0.0182 & 108 & 121 & 38.1 & 55.3 & 41.4 & 87.0 & 178 & 234 & -- & -- \\
\hline 2 & 0.0364 & 117 & 138 & 42.8 & 120.0 & 206.0 & 297.0 & 257 & 278 & -- & -- \\
\hline 3 & 0.0728 & 293 & 318 & 188.0 & 113.0 & 181.0 & 232.0 & -. & 136 & 48.0 & 0.064 \\
\hline 4 & 0.1456 & 452 & 284 & 308.0 & 302.0 & 304.0 & 345.0 & -- & 240 & 84.0 & 0.23 \\
\hline 5 & 0.2912 & -- & -- & 210.0 & 170.0 & 190.0 & 380.0 & -- & 420 & 120.0 & -- \\
\hline 6 & 0.2184 & 68.5 & -- & 475.0 & 465.0 & 535.0 & 395.0 & -- & 225 & 300.0 & -- \\
\hline
\end{tabular}

Note: Height-diameter ratio $\mathrm{H} / \mathrm{D}=4$; length-diameter ratio $\mathrm{L} / \mathrm{D}=20$.

* Pounds of explosive per cubic foot of tunnel.

* Gage locations are shown in fig. 4. 


\section{Appendix A: Soil Analysis}

\section{Objectives}

1. The general objective of the study reported in this appendix was to evaluate soil properties at the tunnel site. Specific objectives were:

a. To identify and classify the physical properties of the soils at the test sites.

b. To provide representative soil strength data near tunnel locations.

c. To provide input parameters for the analytical study of the demolition of shallow tunnels.

The purpose of this appendix is to document the soil strength data for conditions in the vicinity of the tunnels at the time of the demolition tests.

\section{Site Evaluation}

2. A preliminary evaluation of the test site was conducted in August 1967.* Two test pits were excavated, one at each end of the site, and index properties and unconsolidated undrained strengths from these preliminary test pits were determined as summarized in the following tabulations:

\begin{tabular}{|c|c|c|c|c|c|c|c|c|c|c|}
\hline \multirow[b]{2}{*}{ Location } & \multirow[b]{2}{*}{ II } & \multirow[b]{2}{*}{$\underline{\mathrm{PL}}$} & \multirow[b]{2}{*}{$\underline{\mathrm{PI}}$} & Water & \multicolumn{2}{|c|}{ Content } & Dry & $\begin{array}{l}\text { it we } \\
b / f t^{3}\end{array}$ & & \multirow{2}{*}{$\begin{array}{l}\text { Specific } \\
\text { Gravity }\end{array}$} \\
\hline & & & & Min & Avg & Max & Min & Avg & $\operatorname{Max}$ & \\
\hline North & 32 & 22 & 10 & 6.3 & 9.7 & 13.2 & 96.1 & 97.2 & 98.0 & 2.69 \\
\hline South & 43 & 24 & 19 & $7 \cdot 9$ & 12.2 & 14.1 & 94.4 & 96.3 & 97.7 & 2.68 \\
\hline
\end{tabular}

\begin{tabular}{|c|c|c|c|c|c|c|}
\hline \multirow[b]{2}{*}{ Pit } & \multirow[b]{2}{*}{ Iocation } & \multirow[b]{2}{*}{$\begin{array}{c}\text { Depth } \\
\mathrm{ft} \\
\end{array}$} & \multirow{2}{*}{$\begin{array}{c}\text { Avg Shear } \\
\text { Strength } \\
\text { (Unconfined } \\
\text { Compression) } \\
\text { tons } / \mathrm{ft}^{2} \\
\end{array}$} & \multicolumn{2}{|c|}{$\begin{array}{c}\text { Triaxial } \\
\text { Compression Tests }\end{array}$} & \multirow[b]{2}{*}{$\begin{array}{c}\text { Avg } \\
\text { Strain at } \\
\text { Max Stress } \\
\%\end{array}$} \\
\hline & & & & $\begin{array}{l}\text { Apparent } \\
\text { Cohesion } \\
\text { tons } / \mathrm{ft}^{2} \\
\end{array}$ & $\begin{array}{c}\text { Apparent } \\
\text { Friction Angle } \\
\text { deg }\end{array}$ & \\
\hline 1 & North & $3 \cdot 5$ & 5.04 & 2.8 & 27 & 2.0 \\
\hline 2 & South & 4.0 & 3.80 & 2.5 & 28 & 2.6 \\
\hline
\end{tabular}

* Memorandum for Chief, Physical Sciences Branch, NWED, dated 31 Aug 1967, subject: "Preliminary Soil Test at Proposed Tunnel Demolition Test Site," by H. M. Taylor, Jr. 
3. Visual observation of samples and excavations and the results of a seismic survey indicated a uniform soil stratum to a depth of approximately $18 \mathrm{ft}$. Classification according to the Unified Soil Classification System indicated tan silty clay (CL) locally known as "Vicksburg loess."

\section{Sampling and Testing}

4. Samples were taken at the site on 12 and 13 October 1967 from the surface to a depth of $7.5 \mathrm{ft}$ with 5-in.-ID Shelby tubes at two boring locations about $40 \mathrm{ft}$ apart as shown in fig. Al. Conventional laboratory tests were conducted on selected specimens from these samples as described in the following paragraphs.

5. Laboratory testing consisted of routine classification and index tests to identify the soil constituents, water content and density
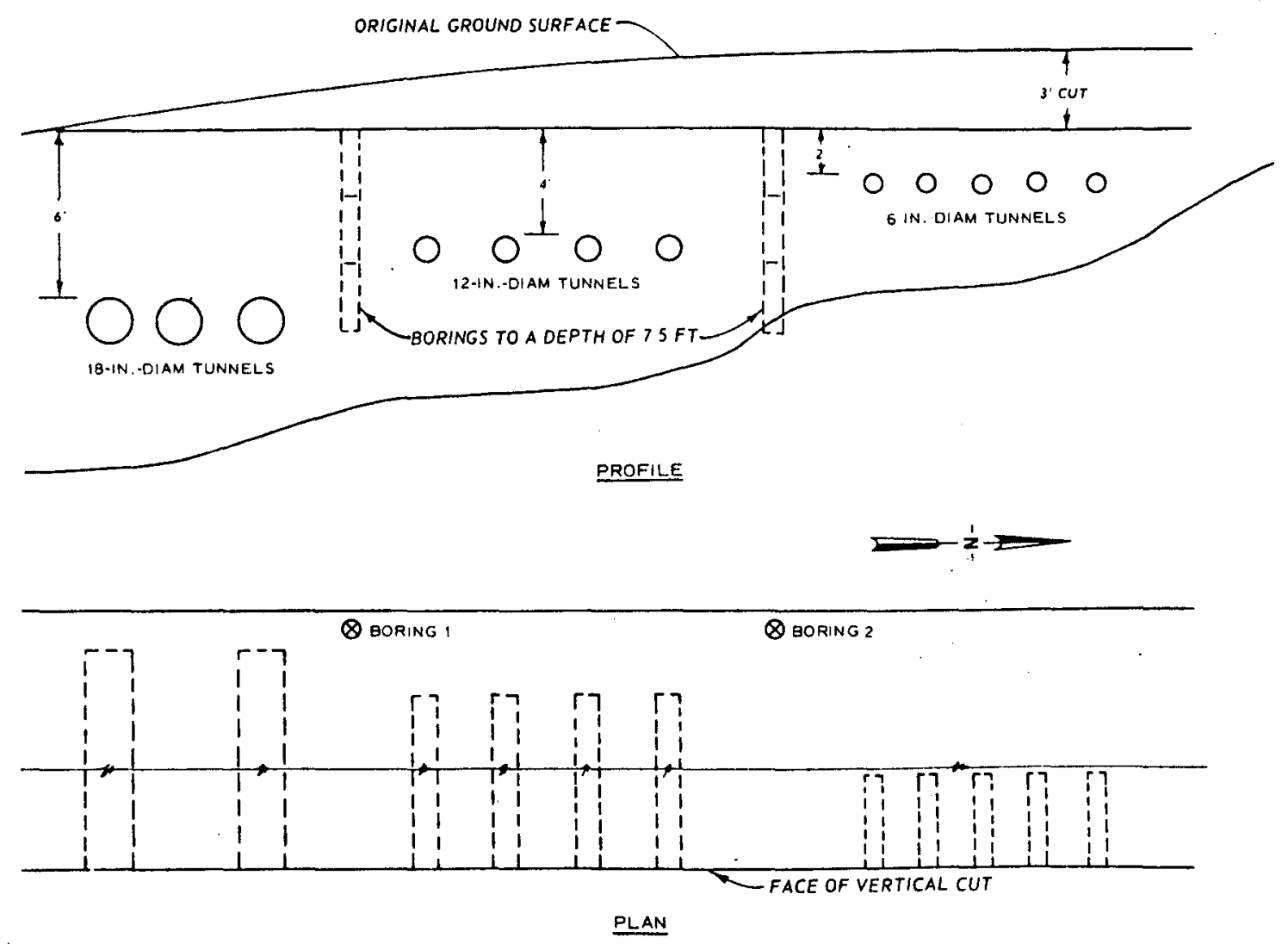

Fig. Al. Approximate boring locations 
determinations to establish in situ composition, and slow and rapid triaxial tests to determine shear strength characteristics. Visual inspection and routine tests indicated that these samples were essentially identical to those obtained from the test pits during the site evaluation except for higher natural water content. Water contents from the test pits were from 6 to $14 \%$ while water contents from the soil borings ranged from 20 to $23 \%$. Rainfall occurring in the time between taking of the two samples was light and not sufficient to account for the observed difference in water content, but the site was graded during the interval. The samples from the borings are representative of the soil conditions prevailing during the actual demolition tests.

\section{Triaxial Compression Tests}

6. Thirty unconsolidated undrained triaxial compression (UU) tests and ten unconfined compression (UC) tests were conducted on 1.4-in.-diam by 3.0-in.-high specimens to determine the shearing resistance of the soil. Eighteen static UU tests and ten UC tests were conducted on samples obtained from the two borings. The strain rate was $3.30 \% / \mathrm{min}$ and confining pressures ranged from 0 to $42 \mathrm{psi}$. The results of the static triaxial and unconfined compression tests are summarized in table Al. Twelve dynamic UU tests were performed on specimens using a rapid triaxial compression device at a strain rate of approximately 330\%/sec and a range of confining pressures from overburden pressure ( 2 to $7 \mathrm{psi}$ ) to $42 \mathrm{psi}$. The results of the dynamic tests are summarized in table A2.

\section{Discussion}

7. Mohr stress circles and strength envelopes for static and dynamic series of tests at approximately the same depths are plotted in fig. A2. From Coulomb's shear strength theory, the failure envelopes are defined by:

$$
\tau_{f}=c+\sigma \tan \varnothing
$$

where

$$
\tau_{f}=\text { shear strength, psi }
$$




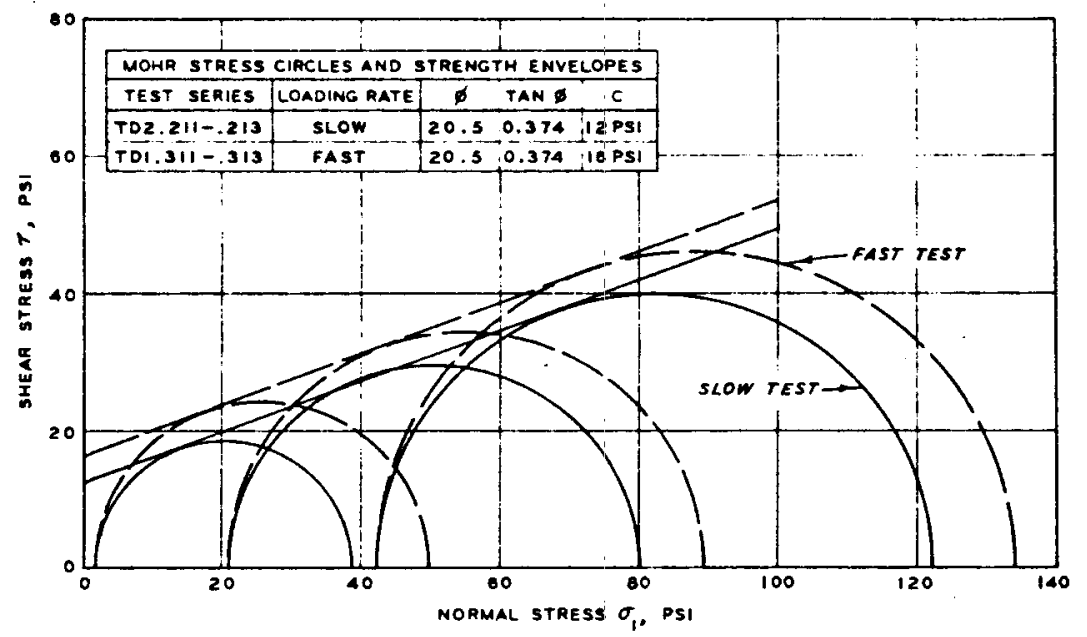

号

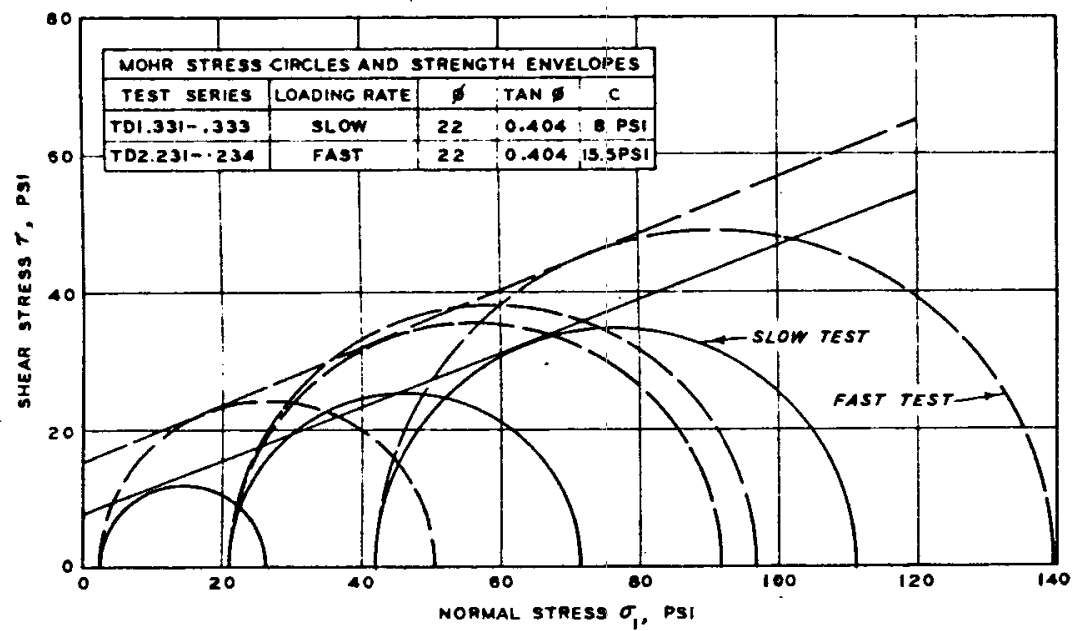

c. BORING 2, SAMPLE 2, DEPTH $=38$ TO $43 \mathrm{IN}$.

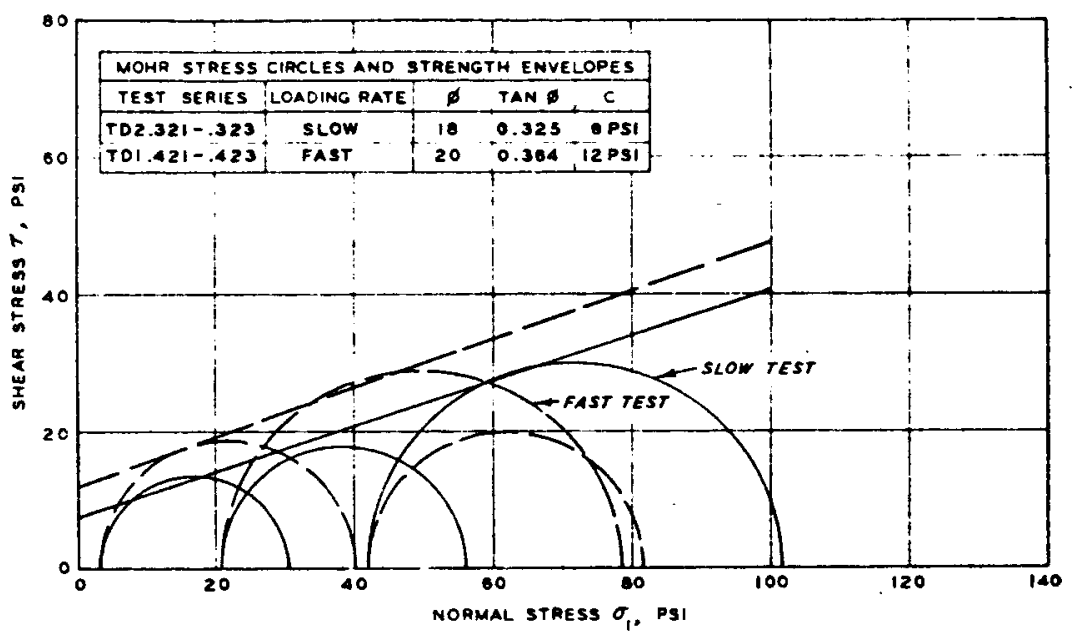

b. BORING I, SAMPLE 4, DEPTH $=48$ TO $52 \mathrm{IN}$.

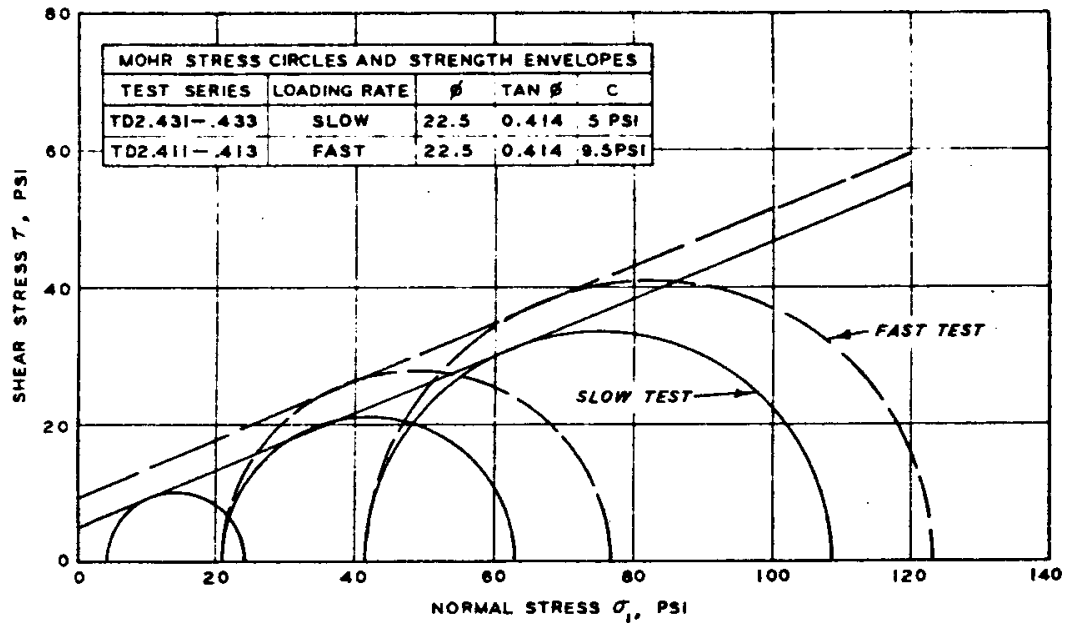

d. BORING 2, SAMPLE 4, DEPTH $=59$ TO $63 \mathrm{IN}$.

Fig. A2. Mohr stress circles and strength envelopes 


$$
\begin{aligned}
& c=\text { apparent cohesion, psi } \\
& \sigma=\text { normal stress, psi } \\
& \varnothing=\text { apparent angle of internal friction, deg }
\end{aligned}
$$

The dynamic failure envelopes lie above, but are generally parallel to, the static envelopes. This observation is interpreted to indicate a sensitivity of the cohesive component of strength to rate of loading, but the friction component is essentially unaffected for this particular soil. An index to the effect of rate of loading, the dynamic-to-static cohesion ratio $c_{d} / c_{s}$ computed from the unconsolidated undrained test results was found to range from 1.3 to 1.9 and average 1.7 .

\begin{tabular}{|c|c|c|c|c|}
\hline Soil Property & $\begin{array}{c}\text { Test Pit } \\
1 \\
\end{array}$ & $\begin{array}{c}\text { Boring } \\
1 \\
\end{array}$ & $\begin{array}{l}\text { Test Pit } \\
2 \\
\end{array}$ & $\begin{array}{c}\text { Boring } \\
2 \\
\end{array}$ \\
\hline Moisture content, $\%$ & 10 & 21 & 12 & 23 \\
\hline Dry unit weight, $1 \mathrm{~b} / \mathrm{ft}^{3}$ & $97 \cdot 2$ & 95.2 & 96.3 & 97.2 \\
\hline UC shear strength, psi & 69.5 & 12.5 & 53 & 15 \\
\hline Apparent cohesion, $*$ psi & 39 & 10 & 35 & 9 \\
\hline Apparent friction angle, $*$ deg & 27 & 21 & 28 & 20 \\
\hline
\end{tabular}

8. A comparison of the average values of the soil properties from the two different sampling locations is given below:

* Static triaxial tests.

These average values are in adequate agreement when comparing one pit with the other or one boring with the other, but shear strength measurements from the borings are definitely lower than those from the pits with respect to both cohesive and frictional components. The differences in shear strength are consistent with variations in water content. Since climatic conditions do not account for the water content variations, it can only be speculated that the observed differences are a consequence of ground water table variations with the natural topography and possible readjustments of soil moisture due to grading of the site. However, the samples from the borings were taken closer to the test tunnels and are believed to be more nearly representative of the shear strength prevailing at the time of the actual demolition tests. 
Table AI

Static Unconsolidated Undrained Strength Summary

\begin{tabular}{|c|c|c|c|c|c|c|}
\hline \multirow[b]{2}{*}{$\begin{array}{c}\text { Depth } \\
\text { in. } \\
\end{array}$} & \multirow[b]{2}{*}{$\begin{array}{c}\text { Avg } \\
\text { Moisture } \\
\text { Content } \\
\% \\
\end{array}$} & \multirow[b]{2}{*}{$\begin{array}{c}\text { Avg } \\
\text { Dry Unit } \\
\text { Weight } \\
\mathrm{lb} / \mathrm{ft}^{3} \\
\end{array}$} & \multirow[b]{2}{*}{$\begin{array}{l}\text { UC Shear } \\
\text { Strength } \\
\text { tons/ft } \\
\end{array}$} & \multicolumn{2}{|c|}{ UU Test } & \multirow[b]{2}{*}{$\begin{array}{c}\text { Avg } \\
\text { Strain at } \\
\text { Max Stress } \\
\% \\
\end{array}$} \\
\hline & & & & $\begin{array}{l}\text { Apparent } \\
\text { Cohesion } \\
\text { tons } / \mathrm{ft}^{2} \\
\end{array}$ & $\begin{array}{c}\text { Apparent } \\
\text { Friction } \\
\text { Angle } \\
\text { deg } \\
\end{array}$ & \\
\hline \multicolumn{7}{|c|}{ Boring I } \\
\hline $5-10$ & 20.2 & 96.4 & -- & 1.05 & 20 & 8.3 \\
\hline $16-20$ & 22.0 & $97 \cdot 3$ & 0.93 & -- & -- & 1.3 \\
\hline $20-24$ & 21.6 & 94.9 & -- & 0.5 & 23 & 11.6 \\
\hline $33-37$ & 21.7 & 95.5 & 0.80 & -- & -- & 1.0 \\
\hline $37-41$ & 20.7 & $95 \cdot 5$ & -- & 0.58 & 21 & 12.3 \\
\hline $50-56$ & 21.1 & 92.4 & 0.94 & -- & -- & 1.0 \\
\hline \multicolumn{7}{|c|}{ Boring 2} \\
\hline $30-34$ & 22.2 & 100.5 & -- & 0.90 & 21 & $9 \cdot 3$ \\
\hline $34-38$ & $22 \cdot 3$ & 99.7 & 1.21 & - & -- & 4.0 \\
\hline $48-52$ & 23.5 & 96.1 & - & 0.69 & 17 & $5 \cdot 3$ \\
\hline $52-56$ & $23 \cdot 1$ & 96.2 & 0.94 & -- & -- & 1.6 \\
\hline $68-73$ & $22 \cdot 3$ & $93 \cdot 7$ & -- & 0.40 & 23 & 10.3 \\
\hline
\end{tabular}

Note: To convert shear strength from tons per square foot to pounds per square inch, multiply by 13.9 .

Table A2

Dynamic Unconsolidated Undrained Strength Summary

\begin{tabular}{|c|c|c|c|c|c|c|c|}
\hline $\begin{array}{l}\text { Bor- } \\
\text { ing } \\
\end{array}$ & $\begin{array}{c}\text { Depth } \\
\text { in. } \\
\end{array}$ & $\begin{array}{l}\text { Avg Mois- } \\
\text { ture Con- } \\
\text { tent, } \% \\
\end{array}$ & $\begin{array}{c}\text { Avg Dry } \\
\text { Unit } \\
\text { Weight } \\
1 \mathrm{~b} / \mathrm{ft}^{3} \\
\end{array}$ & $\begin{array}{l}\text { Appar- } \\
\text { ent Co- } \\
\text { hesion } \\
\text { psi } \\
\end{array}$ & $\begin{array}{c}\text { Apparent } \\
\text { Friction } \\
\text { Angle } \\
\text { deg } \\
\end{array}$ & $\begin{array}{c}\text { Avg } \\
\text { Strain } \\
\text { at Max } \\
\text { Stress, \% } \\
\end{array}$ & $\begin{array}{l}\text { Cohesion } \\
\text { Ratio } \\
c_{d} / c_{s}^{*} \\
\end{array}$ \\
\hline 1.3 & $30-34$ & 21.6 & 93.3 & 16.0 & 20.5 & 8.5 & 1.3 \\
\hline 1.4 & $48-52$ & 21.3 & 93.5 & 12.0 & 20.0 & 3.7 & 1.5 \\
\hline 2.2 & $38-43$ & 22.2 & 96.2 & 15.5 & 22.0 & 8.8 & 1.9 \\
\hline 2.4 & $59-63$ & 22.7 & 91.1 & 9.5 & 22.5 & 8.5 & 1.9 \\
\hline
\end{tabular}

* $c_{s}=$ static apparent cohesion from table Al. 
1. Commanding General

U.S. Army Munitions Command

Dover, New Jersey 07801

ATTN: AMSMU-XC (Liaison Officer - Combat Development Command)

AMSMU-CE (Chief Engineer) AMSMU-QA (Munitions Reliability Division)

AMSMU-RE-E (Engineering Division)

AMSMU-RE-M (Ammunition Systems Engineering Division)

2. Commanding officer

Picatinny Arsenal

Dover, New Jersey 07801

ATTN: SMUPA-RT-S (Library)

SMUPA-DX1 (Editorial \& Pub1ications Section)* 1

SMUPA -W (Explosive Ordnance Disposal Center) 1

SMUPA-DR8 (B.J. Torok)

3. Commanding Genera1

U.S. Army Materie 1 Command

Washington, D.C. 20315

ATTN: AMCRD

4. Commanding General

U.S. Army Test \& Evaluation Command

Aberdeen Proving Ground, Maryland 21005

ATTN: AMSTE

5. Commandant

U.S. Army Ordnance Center \& School

Aberdeen Proving Ground, Maryland 21005

ATTN: AISO-SL

6. Commanding of ficer

U.S. Army Mobility Equipment R\&D Center

Fort Belvoir, Virginia 22060

ATTN: Technical Document Center

7. Defense Documentation Center

Cameron Station

Alexandria, Virginia 22314 
DEPARTMENT OF THE INTERIOR

8. Bureau of Mines 4800 Forbes Avenue Pittsburgh, Pa. ATTN: Dr. R. VanDolch

Dr. D. Burgess

$\underline{\text { ARMY }}$

9. Commanding General

U.S. Army Materiel Command

Washington, 25, D.C.

ATTN: AMCRD-D

AMCRD - DB

AMCRD-I

AMCIS - F

1

1

1

10. Office, Corps of Engineers

Department of the Army

Washington, D.C.

ATTN : ENGTE-EP

ENG-SA

11. Commanding Genera1

U.S. Army Combat Developments Command

Fort Belvoir, Virginia

ATTN: CDCMR $-\mathrm{V}$

SWCA-M

SWCA-D

CAGEN-M

12. Commanding officer

CDC Infantry Agency

Fort Benning, Georgia

13. Commanding Genera1

U.S. Army Combat Developments Command

Special Warfare Agency

Fort Bragg, North Carolina

ATTN: SWA-DSEO

14. Office, Chief of Research and Development Department of the Army

Washington, D.C.

ATTN: OCRD-X 


\section{$\underline{A R M Y ~ C O N T ' D}$}

15. Commanding officer

U.S. Army Engineer Research \& Development Lab

Fort Belvoir, Virginia

ATTN: DMEFB-MW (B.F. Rienhart)

OMEFB-DR (Dr. Howard)

16. Commanding General

U.S. Army Munitions Command Dover, New Jersey

ATTN: AMSMU-RE-M (F.H. Ado1f)

17. Commanding officer

Weapons Development Laboratory

Edgewood Arsena1, Maryland

ATTN : SMUEA-WMW (J. Sansonetti)

18. Commanding officer

U.S. Army Limited War Laboratories

Aberdeen Proving Ground, Maryland

ATTN: Milton Cutler 
Unclassified

Security Clessification

\section{DOCUMENT CONTROL DATA - R \& D}

(Securlfy cleselficetion of tille, body of abotrect and Indexind ennotellon muat be entered when the overall report le claeblfled)

1. ORIGINATING ACTIVITY (Corporale euthor)

U. S. Army Engineer Waterways Experiment Station

Vicksburg, Mississippi

29. AEPONT EICURITY CLASEIFICATION

Unclassified

2b. onoup

3. REPOAT TITLE

DESTRUCTION OF MODEL EARTHEN TUNNELS BY INTERNAL EXPLOSIVE DETONATION

4. OESCRIPTIVE NOTES (Type of repart and inclustre detea)

Final report

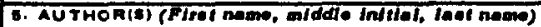

Wallace M. Gay, Mark A. Vispi, James K. Ingram, and Hugh M. Taylor, Jr.

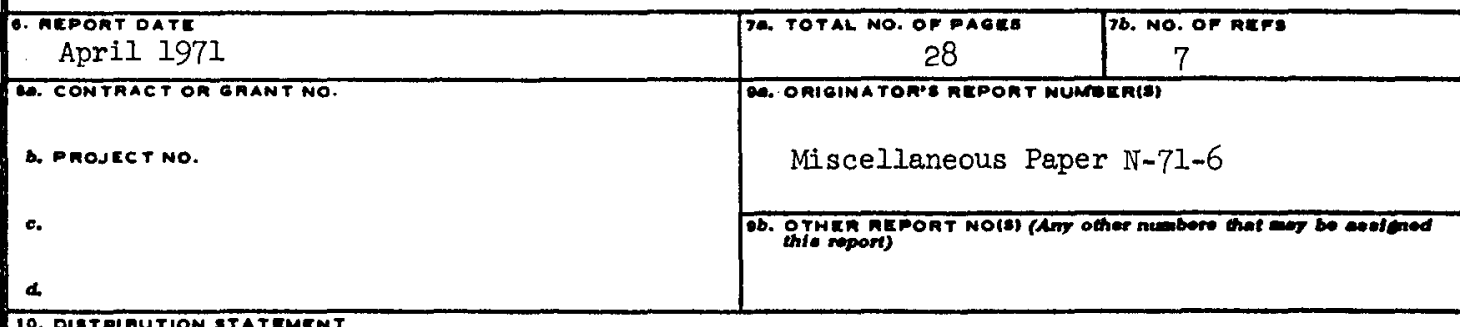

10. DISTAIOUTION STATEMENT

Approved for public release; distribution unlimited.

11. BUPPLEMENTARY NOTES

12. SPONBORING MILITARY ACTIVITY

Picatinny Arsenal

Dover, N. J.

13. ADSTRACT

This report describes a series of explosive demolition tests on small horizontal tunnels in soil using line charges of Primacord. The objectives of the tests were to study the mechanisms of failure of model tunnels in earth when subjected to internal explosions and to develop a means of predicting failure considering the soil properties (detailed in Appendix A) and tunnel geometry. A nondimensional approach to data analysis was proposed to account for the many test variables, including soil properties, geometry, and explosive loading density; although only a limited number of tests were performed, this method of approach appears to be valid. Results for the dominant test condition investigated (depth of cover $H$ four times the tunnel diameter $D$ ) Indicate that a minimum loading density of $0.3 \mathrm{lb} / \mathrm{ft} 3$ of Primacord is required to destroy tunnels in a strong, cohesive soll. A dimensionless plot was constructed from the results of these tests. This plot includes only the condition $\mathrm{H} / \mathrm{D}=4$; therefore, with this plot and a known tunnel size, the amount of Primacord to destroy a tunnel of $H / D=4$ in various strength soils can be determined. 
Unclassified

Security Classification

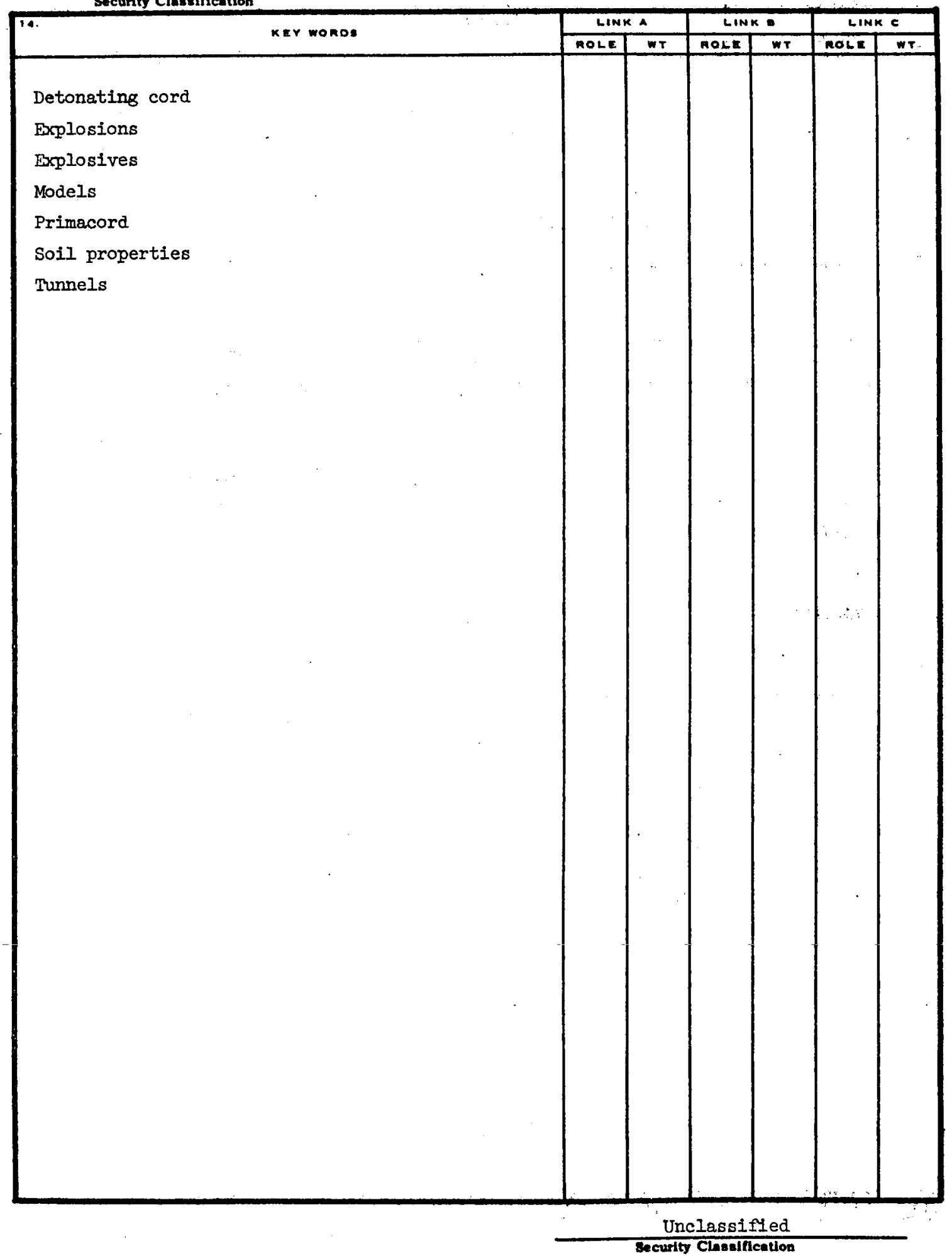

